\title{
Constitutional Design and the Brazilian JUDICIAL REVIEW: REMARKS ABOUT STRONG AND WEAK-Form REVIEW IN THE BRAZILIAN FEDERAL SUPREME COURT
}

\begin{abstract}
Marco Antonio Loschiavo Leme de Barros*
1 Introduction. 2 The Brazilian judicial review system, STF and the strong-form review. 2. 1 A brief overview on the history of the Brazilian judicial review. 2.2 STF and the strong-form review in practice. 3 Variations of a weak-form review in Brazil. 3.1 The writ of injunction (mandado de injução). 3.2 The action of unconstitutionality by omission (ação declaratória de constitucionalidade por omissão). 4 The outcomes of a judiciary reform without a political reform in Brazil. 5 Final remarks. References.
\end{abstract}

\begin{abstract}
This paper discusses the constitutional design model of judicial review established in the 1988 Brazilian Federal Constitution through the classification model of strong and weak judicial review forms, generally applied to the Commonwealth countries. Since the end of the military dictatorship in the late 1980s, Brazil has been following a strong judicial supremacy with a hybrid judicial-review system concentrated very much in the Federal Supreme Court. Nevertheless, this paper argues that at the structural level Brazil's constitutional design could be understood to operate in a weak-form judicial review, where the National Congress is granted the final word on constitutional matters in some situations. This conclusion is reached by analyzing some constitutional provisions and rulings. Despite the fact that Congress rarely overrides - in a responsive manner - the Brazilian Federal Supreme Court's judicial review decisions due to political costs and agenda commitments, I argue that Brazil's weak-form can be exemplified to some extent by highlighting the effects of two different and original constitutional actions: the indirect and concrete judicial review by the writ of injunction (mandado de injunção), to protect fundamental rights, and the direct and abstract judicial review by the declaration action of unconstitutionality by omission (ação declaratória de constitucionalidade por omissão). Both legal actions transfer to the legislator the final word about constitutional issues and some empirical evidence indicates that during the 1990s the Court had a self-contained performance regarding revision power
\end{abstract}

* PhD Candidate at the University of São Paulo Law School (FD-USP). E-mail: <marcoloschiavo@gmail.com>. This paper was granted by the São Paulo Research Foundation (FAPESP) and written during my visiting research stay at University of California - Los Angeles (UCLA), School of Law. I would like to thank the comments of Professor Stephen Gardbaum, the peer reviews and the review assistance of Kevin Massoudi. 
in light of constitutional omissions cases. Finally, the major goal of this paper is to enter into dialogue with the literature of the weak-form judicial review and to encourage a new discussion of application and debate of the model. After all, in an optimal constitutional rule-of-law design, not only do judges play an important role, but the participation of the legislature and executive branch are also required.

Keywords: Constitutional Design. Brazilian Federal Supreme Court. Strong-Form Review. Weak-Form Review.

\section{INTRODUCTION}

The Brazilian Federal Supreme Court (STF) has always been an important player in Brazilian society, it has been decisive not only in legal matters, but also in political, economic and social issues in the last decades. Created at the beginning of the Republic in 1981, the Court was always the highest judicial body and it is known as the safeguard of the 1988 Federal Constitution $(\mathrm{CF} / 88)$. Currently, its jurisdiction is defined in Article 102 of the $\mathrm{CF} / 88$ that establishes a division between constitutional original jurisdiction and an extraordinary appeal jurisdiction. In brief, STF has the last word on many constitutional issues and is also the final appellate instance in the Brazilian legal system.

Despite the fact that the Court suffers under its immense workload - it does not benefit from the writ of certiorari - since the end of dictatorship in the late 1980s, STF started to play a direct role in the political system. In recent years the Court decided several important political controversies vis-à-vis legislative inaction situations, such as the recognition of same sex civil unions, the right to abortion in certain cases (like in pregnancies of fetuses with anencephaly), the implementation of public health programs, the recognition of several affirmative actions and, most recently, ensuring the legal control of the Senate's decision about the President impeachment process.

Brazilian scholarship indicates many reasons for the increased participation of STF in the political arena. We can highlight the redesign of Brazilian judicial-review by $\mathrm{CF} / 88$ and Amendment 45/04 (EC 45) - known as "the Judiciary Reform" - which increased the powers of the Court by fixing new channels through which any citizen could provide a direct claim; ${ }^{1}$ the open texture of the constitutional provisions, mainly with the incorporation of principles that facilitates political debates in the judiciary; ${ }^{2}$ the redemocratization process after the military dictatorship, which facilitated the thematization of certain matters in the courts; ${ }^{3}$ strategic litigation of political opposition who sees STF as an opportunity to reverse political decisions; ${ }^{4}$ and some rulings of the Court that strengthened and expanded its power in the last years. ${ }^{5}$

We can further notice that the political role of STF - carried out by proactive decisions - was built from the social frustrations in recent decades in the country. Annual 
public opinion surveys and databases, like Latinobarómetro or Índice de Confiança na Justiça brasileira/ICJBrasil, reveal that the Legislature and the Executive are insufficiently responsive in relation to the demands of citizens and there is a strong common belief among society that the Judiciary is the last and only legitimate alternative for the solution of political problems in Brazil. ${ }^{6}$

Nevertheless, the emphasis of these analyses has fallen thus on certain bias of empirical variables of the social demands in the Judiciary. We must highlight that many cases do not reach the Court due to costs and many judicial review cases are often captured by middleclass interests, thus it is also very difficult to assert the social validity by framing cases. Strictly speaking, Brazilian constitutional history indicates that courts have been more reactive towards the protection of property and civil rights and very deferential toward the government position rather than adjudicating social and economic rights or promoting social justice.

Despite this practical perspective about judicial review, if we take a closer look at the constitutional structure, not all mechanisms of judicial review operate on the basis of a strong-from judicial review in which STF has the monopoly on the last word of a constitutional matter. Such mechanisms, on the contrary, suggest that the ideal operation would be to sustain a dialogue with the Executive branch and the Legislative, or transferring in some cases the final decision to the Legislature and minimizing the tension between the countermajoritarian judicial control and the democratic decision-making.

From this last perspective, the paper discusses how in some situations it would be more suitable for the Brazilian high court to operate in a weak-form judicial-review, in the manner described by Mark Tusnhnet or Stephen Gardbaum as the new experience of constitutionalism in some Commonwealth Countries. ${ }^{7}$ More precisely, in some cases of legislative omission, the Constituent Assembly deliberately attributed the last word to the National Congress, which can strike down certain rulings on constitutional omission by a simple majority vote.

This hypothesis is counterintuitive and extremely problematic in view of the current role of STF in Brazilian society. However, the aim of this paper is to indicate that even in a country characterized as a strong judicial review model, there also exist mechanisms that encourage the non-monopoly of the final word by the Judiciary and it is possible to address different arrangements of the weak-form design considering the particularities of the Brazilian legal system. ${ }^{8}$

This paper proposes a discussion of the weak model in Brazil, highlighting its specificities and contributing to a more precise and democratic comparative discussion in Constitutional Law. Part II presents the history of judicial review in Brazil and explains the recent strengthening of the judicial review powers of STF. Part III details how despite the characterization of Brazil as having a strong-form judicial-review system, $\mathrm{CF} / 88$ established some mechanisms which require joint action between the Judiciary and the Legislative, and in some cases has granted National Congress the last word on constitutional matters. In this part, I argue the 
possibility of applying the weak form in Brazil by discussing some empirical data, especially in the 1990s when STF had self-contained performance regarding revision power in face of constitutional omissions cases. Part IV explains that in practice and considering the reckless position of the Legislature, such mechanisms have also contributed to the strengthening of the Court's power after "the Judiciary Reform" in 2004. Nonetheless, the analysis of the strengthening of STF in recent years must be accompanied by the study of the political reform debate. Part $V$ finally stresses that in an optimal judicial review design, not only do judges play an important role, but the participation of the Legislature and other branches of government is also required.

\section{THE BRAZILIAN JUDICIAL REVIEW SYSTEM, STF AND THE STRONG- -FORM REVIEW}

Typically, Brazil's judicial review system is conceptualized as a hybrid between the judicial review model of the United States and the European systems, but this idea of legal transplant is wrong and misleading due to the significant differences at the structural and operational level of the Brazilian legal system. All courts in Brazil have the judicial review power in concrete cases, yet only STF has the direct power of striking down statutes and executive acts.

Additionally, it is difficult to find a necessary equivalent in the US or European models of some specific mechanisms and practices of the Brazilian case, if we consider the cultural and historical differences of the development of Public Law. Brazil witnessed a significant expression of social and economic rights, re-distributional policies and public welfare-directed regulation that heavily impacted the judicial review design model in the $\mathrm{CF} / 88$.

This part highlights the history of the development of Brazilian judicial control and explains some of the actual tensions that STF deals with in the strong-form judicial review.

\section{1 A BRIEF OVERVIEW ON THE HISTORY OF THE BRAZILIAN JUDICIAL REVIEW}

Brazil has had eight different constitutional experiences, ${ }^{9}$ with its current version of judicial review developing into what has been called a "hybrid model." The 1824 Imperial Constitution did not have any provision regarding judicial review and it was only in 1890, with the first Republican Constitution, that the US review system was adopted - it was the famous diffuse model, carried out by all courts that were responsible for constitutional control. ${ }^{10}$

Decree no. 848, of 1890, organized federal justice in Brazil and expressly provided the possibility that any court could declare the unconstitutionality of a statute. This initial Brazilian review system underwent some modification with the promulgation of the 1934 
Constitution, which added the direct action of unconstitutionality intervention (ação direta de inconstitucionalidade interventiva). This action sought to solve the federative conflicts in the country and was to be requested exclusively by the Senate. Whenever there was a necessity for federal intervention, that action was to be carried out by a legal act and would have to be submitted to the prior control by the senators.

A second model was established by the 1937 Constitution that provided a new constitutional control by Congress, who could overrule a STF decision by a two-third majority vote. In practice, this turned out to be a powerful mechanism for the authoritarian regime of Getúlio Vargas, since the Congress remained closed during the Estado Novo (1937-1945) and the government assumed the legislative veto power of STF decisions.

Nonetheless, it was during the 1946 Constitution regime, more precisely with Amendment $16 / 1965$, that the representation of unconstitutionality was established. This action inaugurated the abstract model of judicial review in the country with a special proceeding that later become known as the direct action of unconstitutionality (ação direta de inconstitucionalidade - ADI), to be initiated exclusively by the Attorney General of the Republic and decided by STF. Thus, since 1965, Brazil has had a hybrid judicial review system. In the abstract model, STF rulings have ex-tunc, erga omnes and binding effect on the whole Judiciary and Executive branches, and, under the diffuse model, any court—even the STF as a court of appeal - can decide any constitutional issue incidenter tantum and operate extunc and inter partes effect. It is important to highlight that in both models the effects of the decision do not reach the Legislative.

The 1988 Constitution brought four innovations to the hybrid model: 1) the expansion of standing for the proposal of the direct action of unconstitutionality ${ }^{11}$ and extinguishing the monopoly of the Attorney General; 2) allowing states to institute unconstitutionality representations of state statutes in light of state constitutions; 3 ) new forms of abstract review, such as the claim of breach of fundamental precept (arguição de descumprimento de preceito fundamental) - a direct action to protect principles present in the Constitution - and the direct action of constitutionality (ação direta de constitucionalidade) - a direct action that declares constitutional any law or federal norm about which there is controversy or relevant doubt as to the constitutional interpretation; and 4) the judicial review of legislative omission cases, in abstract form, by the direct action unconstitutionality by omission (ação declaratória de constitucionalidade por omissão - ADI by omission), or incidentally, by the concrete control in the case of a writ of injunction (mandado de injunção - MI) - both cases which are examined in this paper.

The last major modifications on the hybrid model were brought by EC 45, which transformed the concrete review model in Brazil. This reform - discussed at length in the 1990s by Brazilian politicians, economists and jurists - was marked by a rationalizing discourse and one of its main goals was to overcome some severe obstacles in the Judiciary that reflected 
into the economic development of the country, such as the legal uncertainty and the lack of predictability of judicial decisions.

In the case of judicial review, the reform created a new filter for the constitutional concrete review in appeal cases, called general repercussion regime (repercussão geral ${ }^{12}$, and the possibility for STF to issue binding precedents (súmulas vinculantes)..$^{13}$ The purpose of these mechanisms was to impart greater effectiveness to the decisions of STF when deciding cases in which there was an important divergence among judicial bodies or between such bodies and the Executive branch.

Such modifications strengthened the Court's review power even more, which now has a quasi-legislative function, and the possibility to control the docket in appeal cases when deciding in the concrete review model. Notwithstanding, over a decade after EC 45, there is still no consensus on whether these mechanisms responded positively to the problem of legal uncertainty and the predictability of judicial decisions in Brazil. The Court's workload continues to grow each year and issuance of binding precedent by STF is a very controversial issue when considering the limits of a court's powers in a Civil Law system.

We discuss in the next topic the practical consequences of the strong control of STF.

\subsection{STF AND THE STRONG-FORM REVIEW IN PRACTICE}

$\mathrm{CF} / 88$ has been as much praised as it has been criticized since its promulgation. On the one hand, the constitutional text is known as the 'citizen's constitution,' which underscores how the constitutional provisions guarantee freedoms, political participation and access to social welfare. Regarding the hybrid judicial review model, recent scholarship confirms an expansion in relation to constitutional control that is widely accessible to any individual, groups and to political actors. Its critics, on the other hand, particularly those in government, consider it a barrier to economic modernization, political governance, and there is concern about the greater power of STF in judicial review.

Given the large provision of social and economic rights, the Brazilian constitutional text is one of the world's longest written constitutions - according to data from Comparative Constitutions Project, if we consider length (in words) as criteria, the CF/88 (with 64.488 words) is just behind the Constitution of India (146.385) and Nigeria (66.263). ${ }^{14}$ Another interesting aspect of $\mathrm{CF} / 88$ is that it has constitutionalized different areas of Law, such as Private Law, Tax Law and Criminal Law. Therefore, almost all areas now befall under the control of judicial review.

For Brazilian scholars, this constitutional profile constrains the governmental agenda and forces rulers to form broad parliamentary alliances in order to change "constitutionalized policies." ${ }^{15}$ Undoubtedly, the fact that a third of the Constitution consists of constitutionalized policies has a strong impact on presidential agendas and has historically forced successive 
governments to rule by changing the constitutional framework via amendments ${ }^{16}$ or even by the judicial review mechanisms. In short, the policy-oriented constitution was a powerful incentive to strengthen court power over the last decade simply because any policy issue may come under scrutiny during judicial review. The current Brazilian model combines a policy-oriented constitution and a strong-form judicial review control carried out by STF.

However, despite the fact that STF has so much power in Brazil, constitutional control is not exclusively in the hands of the Court, since there are also provisions of prior and preventive control exercised by the Legislative and the Executive branches. The legislative control works through its mandatory committee (Comissões de Constituição e Justiça) that constantly analyzes the constitutionality of bills in the legislative process. In the case of the Executive, control occurs with presidential veto power. ${ }^{17}$

Another aspect to consider about the strong review control in Brazil has to do with its low functionality in practice, especially if we compare with the Colombian Supreme Court decisions that systematically challenge the Executive. ${ }^{18}$ Matthew Taylor argues, for instance, that STF has some difficulty to intervene on important policy matters, mainly because of the practical weakness of binding precedents and the formalism within the Brazilian civil law system that usually incentivizes a longer case duration. ${ }^{19}$ In addition, there is in the country an endless appeals process that reflects on the major workload of the Court.

An important report, Supremo em Números, ${ }^{20}$ that analyzed 1,222,102 cases in STF from 1988 until 2009, revealed that almost 92 percent of cases of the Court were appeal cases and less than 1 percent were abstract judicial review cases. Quantitatively speaking STF is not a typical constitutional court, but rather it works more like a "supreme appellate court."

Table 1 - Cases in STF from 1988 to 2009

\begin{tabular}{c|c|c}
\hline Cases & Quantity & Percentage \\
\hline Abstract judicial review & 6,199 & $0,51 \%$ \\
\hline Ordinary Appeal & 95,306 & $7,80 \%$ \\
\hline Extraordinary Appeal & $1,120,597$ & $91,69 \%$ \\
\hline
\end{tabular}

Source: Supremo em Números.

STF is deeply different from classical constitutional courts, since the Court decide cases that go beyond the classical judicial review model and are part of and dependent on the ordinary legal structure. Under Víctor Comella's argument of the dualist structure that makes room for institutional variation of constitutional courts, for instance, STF could be classified as impure and not autonomous. ${ }^{21}$ 
Thus, one problem for a crystal-clear assessment of the constitutional control carried out by STF and the debate of the weak-form is that among those $92 \%$ of extraordinary appeal cases, some had outcomes as typical judicial review decision. Nevertheless, those outcomes occurred frequently and, in an incidental manner in STF, originated from appeal cases and were controlled exclusively by its Justices - there is no constitutional provision establishing any kind of institutional mechanism for a possible control of the Congress in such concrete judicial review situations.

In addition, despite taking part in important disputes of social and political conflicts, the docket of STF in abstract control has been taken by cases related to the delineation of public careers, or cases about the expansion or restraint of state bureaucracy prerogatives. According to Brazilian scholar Oliveira, STF has played the role of a true state corporate deliberation body, deciding systematically in favor of the Executive. ${ }^{22}$ In the same way, another research from Kapiszewski confirmed that STF plays a statesman character, arguing that the Court usually accommodates the interests of elected leaders in its rulings. ${ }^{23}$

When analyzed in practice, the decisions of STF in abstract control - again, which represent less than 1 percent of the Court's workload - showcase a great deference of the Court towards the government's positions, since most cases are related to the state's bureaucracy. This confirms that in practice the Court decides more about constitutional negative rights compared to decisions on constitutional positive duties and collective rights. ${ }^{24}$

Moreover, it is important to highlight that many decisions in abstract control decisions are usually denied - through 2015, 77 percent of STF judgements in abstract review were not granted, which underscores the difficulties of characterizing the Court as truly activist.

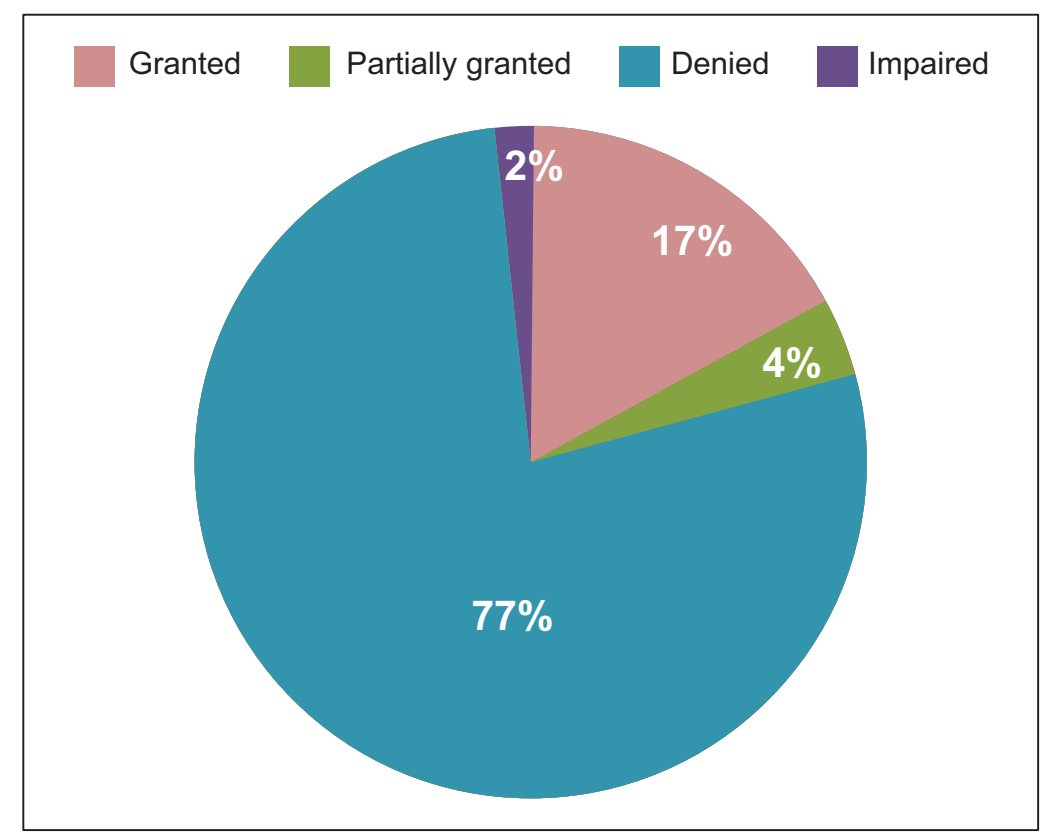

Chart 1 - Judgments by STF in abstract judicial review from 1990 to 2015 Source: STF Database. 
To sum up, we will have a misleading picture of how STF operates de facto if we consider it only as a strong-form judicial review court. Historically the Court has been very deferential to the government and the clear majority of cases decided in abstract judicial-review were not granted; still it is important to highlight again that this represents less 1 percent of the Court's workload and that most decisions of unconstitutionality occur rather in an incidental manner as outcomes from decisions of extraordinary appeal cases.

In the next part, if we take a closer look at the constitutional structure, the current constitutional jurisdiction reveals its originality and diversity in terms of different mechanisms to protect fundamental rights and to control the constitutionality of statutes. As an example of this originality and diversity framework, I discuss the control of constitutionality by omission cases highlighting that this is not an exclusive process that depends only on the Court in Brazil. On the contrary, it requires the participation of the National Congress for settling down problems. This case interestingly indicates that, at the structural level, strong and weak-forms can coexist in a legal framework of judicial review. What this paper suggests is the need for a refinement regarding the descriptive situation and for understanding the real tensions that exist in the judicial review system in Brazil. Finally, it will be possible to question the strict and non-flexible constitutional design models of judicial-review.

\section{VARIATIONS OF A WEAK-FORM REVIEW IN BRAZIL}

The important debate in Comparative Constitutional Law regarding strong and weakform judicial review has never been popular among Brazilian Constitutional Law scholarship, just as the classical distinction between abstract and concrete model. In the long run, it is possible to affirm that this debate has had a great impact in English-speaking countries, especially to differentiate and criticize the supremacy of the US judicial review system when compared to other models that exist in countries such as Canada, the United Kingdom and New Zealand, where at a structural level the final constitutional interpretation rests with the Legislature..$^{25}$

A possible reason for the recent and small debate about the strong and weak-form models in Brazil has to do with the fact that there is a quasi-unanimous understanding among the Brazilian legal community regarding that the strong-form is the best normative solution for the country ${ }^{26}$ and a great deal of scholarship positively evaluate the Court's role as the legitimate channel for social transformation for excluded sectors in the country. ${ }^{27}$ This evaluation is mostly supported by empirical data of the Brazilian society regarding the beneficial outcomes of the proactive decision of STF vis-à-vis the reckless actions by the Executive and the Legislative branches to implement public policies.

Despite the importance of these studies, they miss important aspects present in the strong and weak-form debate about constitutional design. ${ }^{28}$ This debate embodies different 
ways to structure judicial review and discuss how courts and legislatures can relate to each other. In this sense the legitimacy problem of judicial-review remains largely unabated by the Brazilian legal scholarship.

The strong and weak-form debate in Comparative Constitutional Law highlights a common concern about the design options and the everyday operation of the Judiciary and Legislature. The basic premise is to understand that in an optimal constitutional rule-of-law design not only do judges play an important role, but it also requires the participation of the Legislature and the other branches of government. Thus, it is important to understand how normative theorists and constitutional drafters deal with this equilibrium at the structural level.

Brazil is an interesting case to discuss because even if much of the normative output was to confirm the last word to STF, in some situations the National Congress has been granted the last word. The Brazilian legislature can strike down certain rulings by a simple majority when considering constitutional omission cases or even decide directly the same cases without the interference of STF.

This is not a simple truism that every legislature may take decisions without judicial interference - as derived from the principle of the separation of powers. What I argue is substantially different and related with constitutional design. Even though the dialogue and interaction between judges and legislators has not been sufficiently institutionalized in Brazil, legislative backlash spontaneously occurs ${ }^{29}$ and there is still a need for further regulation and protection for a better interaction - just as pointed out by the recent debate about the draft for Constitutional Amendment n.33, of 2011, (PEC 33/11), which attempted to modify the judicial review system in Brazil, ${ }^{30}$ or even for a better control of the judicial review as outcomes from extraordinary appeal decisions.

This situation can be highlighted in practice with some procedural mechanisms of the Brazilian Constitutional Law and the judicial review system.

In a very straightforward way, these mechanisms require a relevant role of the $\mathrm{Na}$ tional Congress, especially in response to decisions of the action of unconstitutionality by omission (ação declaratória de constitucionalidade por omissão - ADI by omission) and the writ of injunction (mandado de injução - MI). These are constitutional instruments that address the problem of legislative omission and the effectiveness of the constitutional text in Brazil.

In such cases, there is no conclusive or final world of the Court, because there is still a pressing need for participation and decision-making of the National Congress. STF rulings in ADI by omission or in MI are provisional and can be easily displaced by a simple majority in Congress. In the next two topics, we discuss in detail these two mechanisms. 


\subsection{THE WRIT OF INJUNCTION (MANDADO DE INJUÇÃO)}

$\mathrm{CF} / 88$ establishes a series of express fundamental rights, from individual and collective to social and economic. Most of these are established in Title II of the charter. In Brazilian Constitutional Law, all the provisions defining fundamental rights and guarantees are immediately applicable, however in some cases the Constituent Assembly established the need for a regulatory legal act in order so as to give full effective force for the constitutional provision. A good example of this situation is the right of public servants to strike. In order to fully exercise this social right, the constitutional text required specific regulation that defines the manner and the limits of the strike (Article 37, VII).

To protect this and many other fundamental rights that still depend on regulation and suffer with the omission of the Legislature or the Executive, CF/88 in article $5^{\text {th }}, \mathrm{LXXI}$, states that "a writ of injunction (MI) shall be granted whenever the absence of a regulatory provision disables the exercise of constitutional rights and liberties, as well as the prerogatives inherent to nationality, sovereignty and citizenship." MI is a "constitutional remedy" - just like habeas corpus, writs of mandamus and habeas data - that specifically deals with the problem of the infectivity of fundamental rights provisions in concrete cases. Thus, whenever a fundamental right cannot be exercised because it has not yet been enacted or regulated by a legal act, any individual has standing to fill a writ of injunction.

There are two basic assumptions for filing a writ: the existence of a fundamental right and the non-existence of a regulatory provision of this fundamental right. The recent Law $13.300 / 2016$ regulates the writ procedure and the main result of STF decision is the declaration of legislative inaction (mora legislativa). In this case, the Court determines a reasonable time for the responsible body to regulate the issue. The regulation, in a broad sense, must establish the conditions under which it will be possible to exercise said rights, freedoms or claimed prerogatives.

It is worth noting that MI can have some similarities with structural interdict or injunctions remedies in Common Law countries since both deal with institutional inaction. ${ }^{31}$ However, there are important differences that make MI very distinctive. MI is an individualized remedy that deals with the problem of non-regulation in a concrete case - a constitutional obligation of the Legislature. There is no supervisory jurisdiction, neither in the form of an order for the government to present a plan or to report back after the implementation of a program. Nevertheless, both mechanisms do not necessarily involve excessive interference with the other powers, and MI specifically was designed to grant the final word to the National Congress.

During the 1990s, one of the most controversial points regarding MI was to know the effects and extension of the court decision, especially towards the legislature. There has been a transformation in the rulings of STF about this matter, from a more self-contained to a more active adjudication regarding the statement of legislative delay. 
From 1988 until the early 2000s, the predominant position of the Court when the writ was granted was only to communicate to the Executive or Legislature about the omission. In this position, STF argued that it was important to defend the strict principle of separation of powers and sustained that it could not regulate the constitutional right or determine the application by analogy of one case that already existed to regulate similar situations.

The fact is that the Court suffers from the problems of an inability to define, regulate and decide cases of legislative omission, mainly because the complexity of the issues that goes beyond mere legal reasoning. In this sense, STF transferred the final decision about the constitutional matter to the legislator, who has the discretion to fix and tailor the situation, according to the democratic process.

An important case that reflects this position was MI 107 that discussed work stability in the military. The main argument stated in the case was that the omission object of MI could not be overcome by the Court's decision since there was a constitutional demand for a political regulation carried out exclusively by Congress - and not an ordinary demand for any kind of regulation. Furthermore, the regulation of work stability of military personnel would impact the government's budget and would have far-reaching political consequences that the Court could not assess.

STF usually argued that in MI cases the decision should respect the opinion of the Constituent Assembly, so as to give the opportunity for the National Congress to decide that matter, mainly because the Legislature could discuss the issues more broadly with the Brazilian society and would be institutionally in a better position to decide vis-à-vis the Court's reasoning restrictions. In this sense, Justice Celso de Mello said that "STF could not replace the Legislator or Executive who were refrained from exercising its normative power. The very exception of this new legal instrument [MI] requires a strict interpretation of the Court about the constitutional principle of separation of powers." ${ }^{32}$

It is worth noting that until 2008 the Court carried on with this position and, based on a study ${ }^{33}$ by Paula Rodrigues Sabra, from a total of 296 MI filed cases, 202 were impaired, because the legislative inaction had been overcome by the legislator before the judgment. Thus, STF had a self-constraining position in omission cases, where issues were turned to the Legislature in order to regulate.

Another interesting fact is that most fundamentals rights that depend on regulation. in Brazilian Constitutional Law, are social and economic rights. ${ }^{34}$ The point is almost intuitive if we consider that social and economic rights depend on policy actions and it is certainly appropriate that the Executive and Legislature have discretion over the issue. What is revealed in the Brazilian Judiciary is that courts have reasoning problems towards the adjudication of distributive rights, weighing policy alternatives and in calculating costs and benefits. ${ }^{35}$ 
However, based on legislative research, not a single social or economic right was regulated as a response of a MI case. Sabra's research - framed until 2008 - points out that out of all cases of legislative inaction, 98 percent had no legislative response stemming from a MI decisions. ${ }^{36}$

Given the low legislative response, and with an almost entirely renewed court composition, STF reviewed its position at the end of 2007, in order to regulate the cases despite Congressional inaction. The paradigmatic decision was MI 721 that discussed the regulation of the right to special retirement of a public servant that exercised for more than twentyfive years the functions as an assistant nurse in a public hospital. Recalling article $40, \S 4$ of $\mathrm{CF} / 88$, the petitioner pointed out that the lack of regulation made her unable to exercise the right to special retirement due to contact with harmful health agents and infectious diseases and materials. ${ }^{37}$ During oral argument, Justice Rapporteur Marco Aurelio said that the Court should deal with the consequences of legislative inaction, and the Court regulated the right to special retirement. ${ }^{38}$

Other paradigmatic cases were MIs 670, 708 and 712, filed by trade unions of public servants, seeking to ensure the right to strike for their members. The Court held by unanimous decision that the inexistence of regulation of the article 37, VII could not provoke an extreme disadvantage for the servants and determined to apply, when possible, the current law on strikes applicable to private sector workers to those in public service. ${ }^{39}$ Justice Eros Grau argued in this case that it was useless just to declare the legislative inaction since this was a constitutional obligation. ${ }^{40}$

Lastly, it is worth noting that this shift in the beginning of the 2000s illustrates the opportunity that the Court had to act strategically in order to strengthen its political powers at the same time they were deciding particular cases.

\subsection{THE ACTION OF UNCONSTITUTIONALITY BY OMISSION (AÇÃO DECLA- RATÓRIA DE CONSTITUCIONALIDADE POR OMISSÃO)}

A very similar mechanism to the writ of injunction is the action of unconstitutionality by omission (ação declaratória de constitucionalidade por omissão - ADI by omission) introduced by article 103, $\$ 2$ which states, "when unconstitutionality is declared on account of lack of a measure to render a constitutional provision effective, the competent Power shall be notified for the adoption of the necessary actions and, in the case of an administrative body, to do so within thirty days."

$\mathrm{ADI}$ by omission is an abstract judicial review model for the specific case when there is any kind of failure in drawing up legislation in regards to a constitutional provision. The purpose of this constitutional action ${ }^{41}$ is to formally declare the Legislature inactive. Thus, also in ADI by omission - at the structure level - there is a direct transfer of the final word to Congress. 
Regarding the effects of the decision of ADI by omission, STF usually notifies the responsible political branch to adopt the necessary measures. $\mathrm{CF} / 88$ specifies that in case of an administrative body, there is a period of 30 days to take the necessary measure. However, for legislative omission, there is no deadline given.

Since the establishment of the constitutional provision of ADI by omission in CF/88, less than 40 cases have been filed, ${ }^{42}$ the vast majority was not granted and there is no notice about any kind of repercussion from the National Congress as a response to a case of an ADI by omission.

ADI by omissions have not become very popular in Brazil, unlike MI, and we can suppose that this was a direct effect from its restrictions for litigation. ADI by omission is not related to any concrete case or subjective right and, like in any other abstract review case, its object is the legislation itself - statute, federal law or administrative norm. Another aspect to consider is that there is a restricted list of litigants that have standing to file direct actions of unconstitutionality.

The historical series of MI versus ADI by omission reveals the differences: from 1990 to 2015, STF decided 22 ADI by omission as compared to the 8,853 cases of writs of injunction. ${ }^{43}$

Also, it is evident the shift occurred with the increase of MIs in 2008 when the Court reviewed its position. This series represents the expansion of the power of STF over time vis-à-vis the reckless position of the Brazilian Legislative.

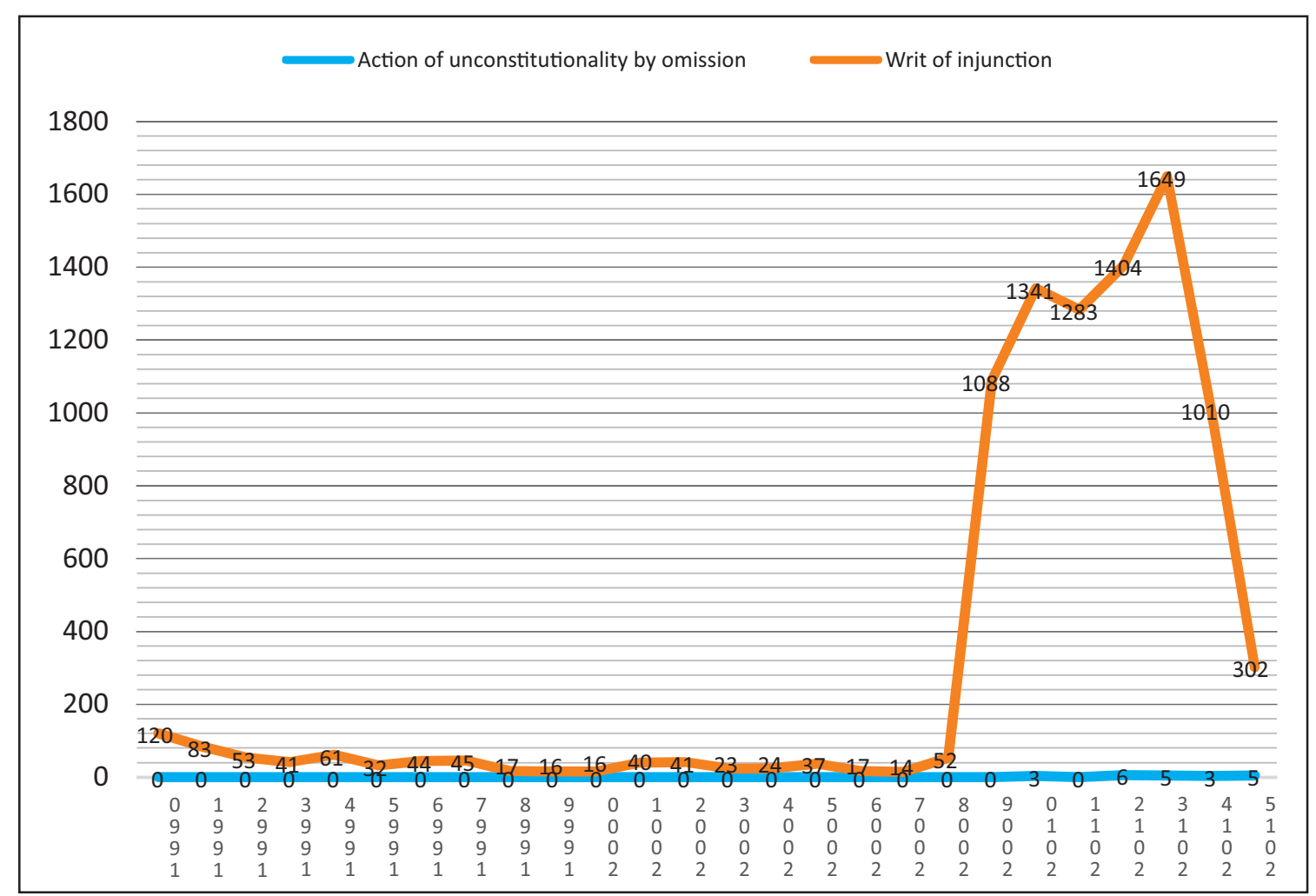

Chart 2 - Judgments by STF in cases of legislative omission from 1990 to 2015

Source: STF Database 
In brief - at the structural level - the Brazilian Constitution establishes some limitations on STF having the last word on interpreting the Constitution, however, in practice there is a very low function. The Legislature has not been decisive in fixing the final constitutional issues in omission cases, and only very exceptionally has Congress responded to decisions by STF.

As a matter of fact, the Brazilian Legislature usually does not work in response, but according to its own interests, even as a veto point to the STF decisions. We can recall that in Brazil the Legislature can easily override a court decision - even in a judicial review case - by passing any statute trying to undo a previous ruling in the ordinary legislative process, a typical legislative backlash.

This situation of legislative overriding can and should reflect - at the operational level - an incentive for dialogue between the institutions, and not a mere backlash. What this paper suggests is the importance to promote a broader perspective of dialogue between the institutions, not only related with the weak-form in the previous omission cases.

The overriding of a STF decision by the Congress should not represent an affront to the judicial authority. In this sense, an important example was that of Law 135/2010, known as the Clean Slate Act (Lei da Ficha Limpa), that established new conditions of ineligibility for political candidates who have been convicted of a crime from running for office, which, in some way, tries to control and eradicate the corruption in Brazilian politics.

In Brazil, it was not possible to disqualify a candidate unless there was a final conviction against him and according to the Court the basis for this understanding laid in the principle of presumption of innocence. The Clean Slate Act overcame this understanding; according to the law, it would not be necessary to have a final conviction for the candidate to become ineligible. Just a simple decision made by a collegiate body (in an ordinary appeal court) was sufficient for them to become ineligible. After the Act, STF reviewed its position when, in a couple of constitutional actions, it held that the legislative response of the Clean Slate Act did not violate the principle of presumption of innocence. ${ }^{44}$

This case, among others, ${ }^{45}$ and the constitutional mechanics highlighted in this part show that in Brazil - at the structural level - there is no absolute and rigid judicial supremacy and it is possible to sustain, in some degree, the operation of a weak-form review. In a broader view, the emphasis here is towards the understanding of the importance of maintaining a dialogical relation between the Judiciary and the Legislature, even for the sake of the separation of powers.

The next part discusses the problems of the operation of weak-form in Brazil. I argue that the weak-form did not thrive in Brazil due to a policy of excessive recourse to the Judiciary and the problems in the political system. To some degree, this was the result of the implementation of the judiciary reform without a political reform that could have established equilibrium in the Brazilian powers during the beginning of the 2000s. 


\section{THE OUTCOMES OF A JUDICIARY REFORM WITHOUT A POLITICAL REFORM IN BRAZIL}

It is possible to discuss the reasons for the failure of the weak-review in Brazil from the perspectives of the outcomes of the judiciary reform (EC 45). There are two main outcomes that represented the diminishing practice of the possibility of transferring the last word of constitutional issues to the Brazilian Legislature. The first consequence, as already pointed out, was the strengthening of the powers of STF, mainly because of the general repercussion regime (repercussão geral) for extraordinary appeals cases and the possibility of issuing precedent with binding effects (súmula vinculante). This first argument indicates that both mechanisms gave quasi-legislative function to the Court. ${ }^{46}$

Nevertheless, another outcome was the incentive of the concentration of many political controversies under STF jurisdiction. This second outcome can be understood due to the previously mentioned 'constitutionalized policies' in CF/88 and to the fact that, since the 2000s, there is a strong "judicialization" (i.e., a great number of cases being brought before the Judiciary) of policy culture ${ }^{47}$ that results from the difficulty of promoting a political reform that could better articulate the powers in Brazil.

This diagnosis is well-known in Brazilian constitutional scholarship: after CF/88 and EC 45 the Judiciary became the main form of dispute resolution in the country - only recently has Brazil adopted alternative measures of conflict resolution, such as mediation and arbitration, in the legal system. What was crucial in this case was the increase of different channels to access the highest court, confirming that judicial review started to be used as a direct policy tactic in Brazil..$^{48}$

Furthermore, another issue was that the judicial reform occurred without the debate about the need for a political reform in the country. As already mentioned, EC 45 was a long and complex legislative process that lasted for more than 12 years in Congress. The major concern at that time was to deal with the problem of judicial efficiency and the need to promote predictability and legal certainty in the country.

After the reform, it became clear that EC 45 had contributed to the increase of judicial interference in political system. Not only at the top of the hierarchy of the courts with STF judicial review power - as discussed in this text - but also in ordinary appeal and local courts that have the power to decide cases of administrative misconduct. ${ }^{49}$

The point to highlight in this part is that during the consolidation of the Brazilian democracy in the 1990s there was a great debate about the articulation of powers in the country. Major reforms were undertaken, such as the modernization of the Executive - mainly with the creation and implementation of regulatory agencies - and the Judiciary reform, yet no political reform occurred. At that time, Brazil was suffering problems of economic hyperinflation, which would only be controlled with the new economic Real Plan (Plano Real), in 
1994, after several failures of economic adjustments that broke the internal market. The concern of the Fernando Henrique Cardoso government (1995-2002) was to promote the modernization of the Executive with the implementation of state reforms and the Judiciary reform, both perceived as mechanisms to consolidate the process of stabilizing the economy, controlling the deficit, recovering public finances and creating favorable conditions for the safe resumption of development. ${ }^{50}$

Nevertheless, once again there was no discussion about a political reform, conceived as a set of changes that could improve the Brazilian party system and be able to keep up with the changes in the Judiciary and in the Executive. Certainly, there was a common belief among statesmen that it was too early to modify the rules of the electoral game since a new constitutional text had just been promulgated in 1988. ${ }^{51}$

Fact is that political reform discussions usually do not thrive in Brazil - like in many other countries - because legislators must decide on rules that will take effect in their own political careers. In addition, the Brazilian party system is highly fragmented, composed of many small and short-lived parties, and often formed around particular personalities. ${ }^{52}$ This scenario makes it very difficult to bring about a broad reform on the political system.

In 2013, former president Rousseff suggested a plebiscite regarding political reform. This plebiscite was a response to the wave of demonstrations over political discontent of the population that took place all over the country. ${ }^{53}$ However, the plebiscite never prospered due to the governing crisis that ended her government with her impeachment, in August 2016. Recently, the Chamber of Deputies has taken over the matter - they created a special commission to deal with the issue,$^{54}$ but it is still not clear what its results will be.

Brazilian scholarship sustains that a broad party system reform may represent a strengthening of the Legislature and an incentive to change policy culture in the country, particularly regarding private campaign financing, and the bargain system between parliamentarians, Executive branches and private actors that sometimes are sustained by corruption schemes. The several proposals need to be discussed with the society broadly. After all, this issue has been demanded by the Brazilian society for a long time. ${ }^{55}$

For the scope of this paper, it is enough to realize that a political reform can contribute to the weak-form in Brazil by equalizing STF decisions with a responsive legislature in the omission cases. Moreover, a new composition of the legislature, with parliamentarians committed with party causes and engaged in public debate with other powers, could be envisioned. All these ideas facilitate the institutionalization of mechanisms that underscore the social control over decision-making on constitutional matters and are an incentive to dialogue between powers. At the same time, instruments of consultation between the Judiciary and Legislature, just like advisory opinions, or even the structural injunctions experiences in other countries could also be considered. 
In brief, the actual centralized model of policy solution carried out by the Judiciary in Brazil is not enough to deal with the tensions between the burdens of the political decisionmaking and the counter majoritarian features of the Court. It is important to note that the Executive and Legislative branches usually hand over some risky issues to the legal system when they decide not to intervene via judicial review cases.

Nevertheless, the Judiciary will also have many internal problems, especially regarding the limitations of legal reasoning that makes it difficult for the Court to assess the best political decision for the Brazilian society. The political system should regulate the matter and thus take responsibility for the consequences, since judges and courts have no adequate conditions in Brazil - in light of the separation of powers - to intervene directly in political issues or to safeguard by incurring costs, otherwise even judicial decisions will not be guarantee against surprises.

\section{FINAL REMARKS}

The main purpose of this paper was to debate the constitutional design and the judicial review in Brazil in light of some consideration of the framework of Compared Constitutional Law on strong and weak-forms.

One of the challenges was to understand how important it is to discuss this debate outside the familiar settings of the comparison of the US Supreme Court and the British Parliament or other common law countries. Our considerations reveal that the debate about strong or weak-forms is a normative one and, actually, it is a discussion about a spectrum with different variations that goes from strong to weak, there is not just one defined form.

It does not matter if the debate takes place in Brazil or elsewhere, there is always a design question that deals with the tensions between the powers. In this sense, some important remarks from Aileen Kavanagh remind us that even in a very traditional country of weak-form judicial review, like the United Kingdom, there can be, in practice, legislatures that do not want and do not operate the last word, thus suggesting that there are many factors that determine strong or weak-form. ${ }^{56}$ Although empirical assessment is fundamental, it is not possible to deny the interference of the normative aspect in question.

Brazil's case demonstrates that it is possible to combine in the same framework instruments that operate in the strong and weak-form. The omission cases actually reveal the complexity of the issue when designing mechanisms, since judicial review can have several forms, combinations and outcomes in a specific constitutional regime.

The paper also suggested that, de facto, the weak-form actually did not fully operate in Brazil due to the high "judicialization" of policy culture and problems in the political system. The turning point was EC 45, in the beginning of the 2000s, which strengthened the Court's review power. There is no doubt that, overall, Brazil adopts and works in a strong-form, 
but this option also did not resolve the tensions between the counter majoritarian judicial control and the democratic decision-making in the country. Instead - by highlighting some contextual issues of $\mathrm{CF} / 88$ - I argued that this option of a strong court increased excessively the political power of STF and the risk of dysfunctional operation of the legal system.

The dysfunctional operation can be simply understood as the fact that judges and courts are progressively abdicating to incorporate the predictability of the legal consequences by dealing with political issues. Moreover, other aspects - that were not examined - can be correlated to the dysfunctional operation, such as a set of principles that created a broader margin of argumentation to STF and the increase of individual powers of its Justices.

Additionally, I stressed that there is a normative weakness in the strong-form in Brazil that was not equated in EC 45, especially if it one considers the pressing need for a political reform in the country and the legal reasoning restrictions when the Court is dealing with distributive kind of rights. All these problems affect the legitimacy of the judicial review in the country, mostly if we consider that there is still an elite control of the legal system as a kind of inheritance from the military dictatorship. As a matter of fact, it is not a surprise that still today the most common litigants in the Judiciary are the government branch and upper and middle-classes that can deal with the judicial costs.

As a result of this, the Judiciary tends to be an exclusive arena for internal solutions of problems from the political branches - like the mention of STF as 'state's corporate deliberation body' highlighted in the paper - or for privileged claimants based purely on their capacity to access the Judiciary and less a space for transformation related with the adjudication of social and economic rights or social justice. ${ }^{57}$

A new arrangement of judicial review should take that into account in Brazil. Neither strong nor weak-form, but a specific form that could attend the needs of the Brazilian democracy and in the extent of other Latin American countries. In this sense it is possible to recall the "pragmatic" argument of potential benefits from weak-form in the context of transitional democracies, as described by Stephen Gardbaum, who mentions that the weakform might reduce the pressures that judicial review places on judges, helping to improve legal reasoning, at the same time that it can actually decrease the tensions between court and political bodies. ${ }^{58}$

Nevertheless, it is not possible to be naïve and believe that the weak-form will eliminate all political tension between the government branch, the Legislative and the courts. The new arrangement - more dialogical - can have better outcomes if courts can also engage in public debate, prompting the responses of the Executive and Legislative branches to act on the decisions reached through the democratic deliberative process. Still, the important question that follows is to know if the framework (strong or weak-form) works from the standpoint of democratic regime stability. Certainly this is a context matter, not only adjusted by reforms, and that needs to be debated at large with the society locally and globally. 


\section{REFERENCES}

ARANTES, Rogério. The Federal Police and the Ministério Público. In: POWER, Timothy; TAYLOR, Matthew. Corruption and Democracy in Brazil. Notre Dame: University of Notre Dame Press, 2010. p. 184-217.

ARANTES, Rogério; COUTO, Cláudio. Constitutionalizing Policy: the Brazilian Constitution of 1988 and its Impact on Governance. In: NOLTE, Detlef Nolte; SCHILLINGVACAFLOR, Almut. New Constitutionalism in Latin America: Promises and Practices. Burlington: Ashgate Publishing, 2012. p. 203-222.

ARGUELHES, Diego Werneck; RIBEIRO, Leandro Molhano. Creature and/or Creator: the Brazilian Supreme Court's Transformations under the 1988 Constitution. Revista Direito GV, São Paulo, v. 12, n. 2, p. 405-440, 2016.

ARIDA, Pérsio; BACHA, Edmar; LARA-RESENDE, André. Credit, Interest and Jurisdictional Uncertainty: Conjectures on the Case of Brazil. In: GIAVAZZI, Francesco; GOLDFAJN, Ilan; HERRERA, Santiago (Org.). Inflation Targeting, Debt, and the Brazilian Experience: 1999 to 2003. Cambridge, MA: MIT Press, 2005.

BARROSO, Luis Roberto. Judicialização da política, ativismo judicial e legitimidade democrática. Revista Jurídica da Presidência, Brasília, v. 12, n. 96, p. 3-41, 2010.

BRASIL. Supremo Tribunal Federal. ADC 29/DF. Rel. Luiz Fux, DJe de 29 de junho de 2012. Available at: $<$ http://redir.stf.jus.br/paginadorpub/paginador.jsp?docTP $=$ TP\&docI $\mathrm{D}=2243342>$.

. Supremo Tribunal Federal. ADC 30/DF. Rel. Luiz Fux, DJe de 29 de junho de 2012. Available at: $<$ http://redir.stf.jus.br/paginadorpub/paginador.jsp?docTP $=$ TP\&docID $=2243411>$.

. Supremo Tribunal Federal. ADI 3.772/DF. Rel. Min. Ricardo Lewandowski, DJe de 26 de março de 2009. Available at: <http://redir.stf.jus.br/paginadorpub/paginador.jsp?doc $\mathrm{TP}=\mathrm{AC} \& \operatorname{doc} \mathrm{ID}=605033>$.

. Supremo Tribunal Federal. MI 670/ES. Rel. Min. Gilmar Mendes, DJ de 31 de outubro de 2008. Available at: $<$ http://redir.stf.jus.br/paginadorpub/paginador.jsp?docTP= $\mathrm{AC} \& \operatorname{doc} \mathrm{ID}=558549>$.

. Supremo Tribunal Federal. MI 721/DF. Rel. Min. Marco Aurélio, DJ de 30 de novembro de 2007. Available at: <http://redir.stf.jus.br/paginadorpub/paginador.jsp?docTP= AC\&docID $=497390>$.

. Supremo Tribunal Federal. MI 107-3/DF. Rel. Min. Moreira Alves, DJ de 21 de setembro de 1990. Available at: <http://redir.stf.jus.br/paginadorpub/paginador.jsp?docTP= AC\&docID $=81908>$. 
BUSTAMANTE, Thomas; VILLANI, André. Diálogos institucionais: a PEC/33 e o discurso jurídico no Legislativo e no Judiciário. In: ENCONTRO NACIONAL DO CONPEDI, 22., 2014, Florianópolis. Anais... Florianópolis: FUNJAB, 2014. p. 179-202.

COMELLA, Víctor. The Consequences of Centralizing Constitutional Review in a Special Court: Some Thoughts on Judicial Activism. Texas Law Review, v. 82, p. 1705-1736, 2004. ESQUIROL. Jorge L. The Fictions of Latin American Law. [S.l.]: Utah L. Rev. 425, 1997. FALCÃO, Joaquim et at. I Relatório supremo em números: o múltiplo supremo. Rio de Janeiro: FGV Direito Rio, 2011. Available at: <http:/hdl.handle.net/ 10438/10312>.

GARDBAUM, Stephen. Are Strong Constitutional Courts Always a Good Thing for New Democracies? Columbia Journal of Transnational Law, United States, v. 53, n. 2, p. 285320, 2015.

. The New Commonwealth Model of Constitutionalism: Theory and Practice. Cambridge: Cambridge University Press, 2013.

KAPISZEWSKI, Diana. Challenging Decisions: High Courts and Economic Governance in Argentina and Brazil. Cambridge: Cambridge University Press, 2007.

KAVANAGH, Aileen. What's So Weak About Weak-Form Review? The Case of the UK Human Rights Act 1998. Int J Const Law, v. 13, n. 4, p. 1008-1039, 2015.

LANDAU, David; MURCIA, Julián Daniel López. Political Institutions and Judicial Role: An Approach in Context, the Case of the Colombian Constitutional Court. VNIVERSITAS, Bogotá, v. 119, p. 55-92, 2009.

LOPES, José Reinaldo de Lima. Brazilian Courts and Social Rights: A Case Study Revisited. In: GARGARELLA, Roberto; DOMINGO, Pilar; ROUX, Theunis. Courts and Social Transformation in New Democracies: An Institutional Voice for the Poor? Burlington: Ashgate Publishing, 2006.

MENDES, Conrado Hubner. Neither Dialogue nor Last Word. Legisprudence, Oxford, v. 5, p. 1-40, 2011

NAGLE, Luz Estella. The Cinderella of Government: Judicial Reform in Latin America. California Western International Law Journal, v. 30, n. 2, p. 345-379, 1999.

NOBRE, Marcos; RODRIGUEZ, José Rodrigo. Judicialização da política: déficits explicativos e bloqueios normativistas. Novos Estudos Cebrap, São Paulo, n. 91, p. 5-20, 2011

OLIVEIRA, Fabiana Luci. Supreme Agenda: Interests in Dispute in Judicial Review in Brazil. Tempo Social, São Paulo, v. 28, n. 1, p. 105-133, 2016.

RIOS-FIGUEROA, Julio; TAYLOR, Matthew. Institutional Determinants of the Judicialisation of Policy in Brazil and Mexico. Journal of Latin American Studies, v. 38, n. 4, p.739-766, 2006. 
SABRA, Paula Rodrigues. Mandado de Injunção: há uma resposta do Poder Legislativo ao instituto? 2008. Available at: <http://www.sbdp.org.br/arquivos/monografia/127_paula. pdf $>$.

TAYLOR, Matthew. Judging Policy: Courts and Policy Reform in Democratic Brazil. Califórnia: Stanford University Press, 2008.

. The Riddle of High Impact, Low Functionality Courts in Brazil Rev. Econ. Polit., São Paulo, v. 25, n. 4, p. 418-438, 2005.

TUSHNET, Mark. Weak-Form Judicial Review and "Core" Civil Liberties. Georgetown Law Faculty Publications and Other Works. 2006. Available at: < http://scholarship.law. georgetown.edu/facpub/240>.

. Weak Courts, Strong Rights: Judicial Review and Social Welfare Rights in Comparative Constitutional Law. Princeton: University Press, Princeton, 2008.

VERÍSSIMO, Marcos Paulo. A Constituição de 1988, vinte anos depois: suprema corte e 'ativismo judicial à brasileira'. Revista Direito GV, São Paulo, v. 4, n. 2, p. 407-440, jul./ dez. 2008

VIANNA, Luiz Werneck et al. Dezessete anos de judicialização política. Tempo Social, v. 19, p. 39-85, 2007

VIERIA, Oscar Vilhena. Supremocracia. Revista Direito GV, São Paulo, v. 4, p. 441-459, 2008.

WALDRON, Jeremy. The Core of the Case against Judicial Review. The Yale Law Journal, New Haven, v. 115, p. 1346-1406, 2006.

1 See VIANNA, Luiz Werneck et al. Seventeen years of judicializing politics. Tempo Social, São Paulo, v. 19, n. 2, p. 39-85, 2007.

2 See BARROSO, Luis Roberto. Judicialização da política, ativismo judicial e legitimidade democrática. Revista Jurídica da Presidência, Brasília, v. 12, n. 96, p. 3-41, 2010.

3 See NOBRE, Marcos; RODRIGUEZ, José Rodrigo. Judicialização da política: déficits explicativos e bloqueios normativistas. Novos Estudos, São Paulo, n. 91, p. 5-20, 2011. See more generaly RODRIGUEZ, José Rodrigo. Society against State: the brazilian crisis beneath the surface. 2016. Available at: <http:/logosjournal. com/2016/rodriguez/>.

4 See TAYLOR, Matthew. Judging policy: courts and policy reform in democratic Brazil. Califórnia: Stanford University Press, 2008.

5 See ARGUELHES, Diego Werneck; RIBEIRO, Leandro Molhano. Creature and/or creator: the Brazilian Supreme Court's transformations under the 1988 Constitution. Revista Direito GV, São Paulo, v. 12, n. 2, p. 405-440, 2016.

6 The recent ICJ Brasil surveys (2009-2016) indicates that the judiciary is one of the most reliable institutions in the country, just staying behind the Brazilian Armed Forces and the Catholic Church. Moreover, the judiciary is commonly accepted as a political force that deals with the inaction problems of other institutions. Available at: <http://bibliotecadigital.fgv.br/dspace/handle/10438/6618>.

7 Following these authors, the weak model have three essential features: (1) the existence of a bill of rights; (2) the conference of some form of judicial improved power to enforce those rights through evaluation of con- 
sistency of legislation and other governmental acts with these fundamental rights, which must go beyond the traditional presumption and ordinary modes of normative interpretation; and more clearly, (3) the existence of a legislature that has the final word on the constitutionality of laws in the country, by simple majority vote. See GARDBAUM, Stephen. The new commonwealth model of constitutionalism: theory and practice. Cambridge: Cambridge University Press, 2013, or TUSHNET, Mark. Weak Courts, Strong Rights: Judicial Review and Social Welfare Rights in Comparative Constitutional Law. Princeton: University Press, Princeton, 2008, also TUSHNET, Mark. Weak-Form Judicial Review and "Core" Civil Liberties. Georgetown Law Faculty Publications and Other Works. Available at: <http://scholarship.law.georgetown.edu/facpub/240>, 2006.

8 This issue reinforces the argument of the difficulty about the ideal constitutional design of judicial review and how to operate vis-à-vis the local culture and practices on judicial decision-making. This argument is also a critique to the law and development narrative of a "failed" law in Latin America and the endorsement of a necessity of a major reform by importing some successful design legal model from a more developed country law, often similar to the United States or Europe. A very good example of this discourse and project was the judicial reform that occurred by the end of the 1990s in most Latin America countries and it was embraced by the World Bank and IMF in order to adjust a macroeconomic agenda in the region. See ESQUIROL. Jorge L. The Fictions of Latin American Law. [S.1.]: Utah L. Rev. 425, 1997. And NAGLE, Luz Estella. The cinderella of government: judicial reform in Latin America. California Western International Law Journal, v. 30, n. 2, 1999.

9 The longest Brazilian Constitution for 65 years was the Imperial Constitution (1824), after the proclamation of the Republic there had been different constitutional experiences: 1891, 1934, 1937, 1946, 1967, 1969 and the actual 1988 Federal Constitution.

10 Rui Barbosa, an important Brazilian statesman that participated in the constituent assembly of the First Republic, confessed in several reports the direct influence of Madison and Hamilton writings in the Brazilian Constitution.

11 In Brazil, according article 103 of the Constitution and after the Judiciary Reform, can only file direct actions of unconstitutionality and declaratory actions of constitutionality: the President of the Republic; the directing board of the Federal Senate; the directing board of the Chamber of Deputies; the Directing Board of a State Legislative Assembly or of the Federal District Legislative Chamber; State Governor or the Federal District Governor; the Attorney-General of the Republic; the Federal Council of the Brazilian Bar Association; political party represented in the National Congress and confederation of labor unions or a professional association of a nationwide nature.

12 The 1988 Constitution in article 102, Paragraph 3 says "[i]n an extraordinary appeal, the appealing party must demonstrate the general repercussion of the constitutional issues discussed in the case, under the terms of the law, so that the Court may examine the possibility of accepting the appeal, and it may only reject it through the opinion of two thirds of its members"

13 The 1988 Constitution in article 103-A says "[t]he Federal Supreme Court may, ex-officio or upon request, upon decision of two thirds of its members, and following reiterated judicial decisions on constitutional matter, issue a binding precedent (restatement of case law) which, as from publication in the official press, shall have a binding effect upon the lower bodies of the Judicial Power and the direct and indirect public administration, in the federal, state, and local levels, and which may also be reviewed or revoked, as set forth in law"

14 The Comparative Constitutions Project is a database cataloguing the world's constitutions since 1789. More information about the Comparative Constitutions Project is available at: <http://www.comparativeconstitutionsproject.org/>.

15 See ARANTES, Rogério; COUTO, Cláudio. Constitutionalizing policy: the Brazilian Constitution of 1988 and its impact on governance. In: NOLTE, Detlef Nolte; SCHILLING-VACAFLOR, Almut. New Constitutionalism in Latin America: promises and practices. Burlington: Ashgate Publishing, 2012. v. 1. p. 203-22.

16 This position is explained by Brazilian scholars Rogério Arantes and Claúdio Couto who confirm that the 1988 Constitution has become the country's great ordinary law and one can predict that government agendas will involve changes to the constitutional framework, with significant political and economic costs for future generations. They affirm that a cycle exists: the more a Constitution embodies public policies, the longer the text is; the longer the text is, the more it forces governments to govern by means of constitutional amendments; and the more a constitution is amended, the longer it becomes. See Arantes and Couto, supra note 14. 
17 It is also important to stress that the legislative can overturn the executive's veto decision, according to article 66 , paragraph 4 of $\mathrm{CF} / 88$ that says "the veto shall be examined in a joint session, within thirty days, counted from the date of receipt, and may only be rejected by the absolute majority of the Deputies and Senators, by secret voting".

18 We can mention the leading case of President Alvaro Uribe where the court held that the president two-term could not be amend for a third term or the doctrine of unconstitutional state of affairs in some social and economic cases. See LANDAU, David; MURCIA, Julián Daniel López. Political Institutions and Judicial Role: An Approach in Context, the Case of the Colombian Constitutional Court. VNIVERSITAS, Bogotá, v. 119, p. 55-92, 2009. p. 55.

19 See TAYLOR, Matthew M. The riddle of high impact, low functionality Courts in Brazil Rev. Econ. Polit., São Paulo, v. 25, n. 4, p. 418-438, 2005. p. 418.

20 See FALCÃO, Joaquim et at. I Relatório supremo em números: o múltiplo supremo. Rio de Janeiro: FGV Direito Rio, 2011. Available at: < http://hdl.handle.net/ 10438/10312>.

21 Victor Comella consider the classical framework of the European Constitutional Courts of the early twentieth century - theorized by Hans Kelsen - where constitutional courts would be completely autonomous. They would be separated from the ordinary judiciary and entirely "pure" because they would only take care of constitutional issues in the abstract. See COMELLA, Víctor. The consequences of centralizing constitutional review in a special court: some thoughts on judicial activism. Texas Law Review, v. 82, p. 1705-1736, 2004.

22 See OlIVEIRA, Fabiana Luci. Supreme agenda: interests in dispute in judicial review in Brazil. Tempo soc., São Paulo, v. 28, n. 1, p. 105-133, 2016.

23 See KAPISZEWSKI, Diana. Challenging decisions: high courts and economic governance in Argentina and Brazil. Cambridge: Cambridge University Press, 2007. Ph.D. diss., Department of Political Science, University of California, Berkeley.

24 See Oliveira supra note 22.

25 It is not surprising that the most influential works in these debates are from North American and Commonwealth scholars - just for a good example like Mark Tushnet and Stephen Gardbaum - and more broadly scholars that stand for an objection towards the judicial review - the classical case with Jeremy Waldron. See WALDRON, Jeremy. The core of the case against judicial review. The Yale Law Journal, New Haven, v. 115, p. 1346-1406, 2006.

26 An important example of this position was the debate about the draft for constitutional amendment n.33 from 2011 (PEC 33/11), which attempted to expand the mechanisms of weak-form review in Brazil. PEC $33 / 11$ was based on the premise that STF is exceeding its powers. As a means of containing such excess, it was intended: (i) to modify Article 97 of the $\mathrm{CF} / 88$ to raise the voting quorum for unconstitutionality; (ii) to raise the quorum of binding precedentes (súmulas vinculantes) from $2 / 3$ to $4 / 5$ and to be mandatory approved by the National Congress, and (iii) the condition that the erga omnes effect of STF decisions would be scrutinized by the National Congress. PEC 33/2011 got rejected from both the political class and the legal community, some arguments that were used to refuse the draft was the offense of the principle of separation of powers and the eternity clause from the Article 60 paragraph 4th of the CF/88. See BUSTAMANTE, Thomas; VILLANI, André. Diálogos institucionais: a PEC/33 e o discurso jurídico no Legislativo e no Judiciário. In: ENCONTRO NACIONAL DO CONPEDI, 22., 2014, Florianópolis. Anais... Florianópolis: FUNJAB, 2014. p. 179-202.

27 For a general and positive evaluation about the expansion of the court role see VERÍSSIMO, Marcos Paulo. A Constituição de 1988, vinte anos depois: suprema corte e 'ativismo judicial à brasileira'. Revista Direito GV, São Paulo, v. 4, n. 2, jul./dez. 2008 and VIANNA, Luiz Werneck et al. Dezessete anos de judicialização política. Tempo Social, v. 19, p. 39-85, 2007. In addition, an important reference about the expansion of STF powers is the work of Vieira about the 'Supremocracy'. See VIERIA, Oscar. Supremocracia. Revista Direito GV, São Paulo, v. 4, p. 441-459, 2008.

28 The issue about constitutional design is also present in another degree in the discussion of the last word in different models of deliberative democracies, the central question is: who should have the last say about a constitutional issue in a democracy? Extensive political science literature answers this question with three possibilities: "theories of last word" that usually accepts two opposing answers (either supreme courts or elected legislature), "theories of dialogue" that rejects the last word option and "moderate theories" that accepts the provisional last word that is based in a flowing rather than static idea of separation of powers. Usually these 
theories characterize the court as a deliberative catalyst capable of discerning good and bad arguments. See MENDES, Conrado Hubner. Neither dialogue nor last word. Legisprudence, Oxford, v. 5, p. 1-40, 2011.

29 Furthermore, the Constitution does not prohibit the idea of legislative backlash, especially considering that in Article 102, Paragraph 2 of CF/88 says: [f] inal decisions on merits, pronounced by the STF, in direct actions of unconstitutionality and declaratory actions of constitutionality shall have force against all, as well as a binding effect, as regards the other bodies of the Judicial Power and the governmental entities and entities owned by the Federal Government, in the federal, state, and local levels.

30 See supra note 25.

31 See the famous Government of the Republic of South Africa and Others $v$ Grootboom and Others -, or even in the US Supreme Court arguing the equal protection clause on civil right cases - like Brown v. Board of Education of Topeka - in both cases the constitutional courts applied injunction remedies.

32 See BRASIL. Supremo Tribunal Federal. MI 107-3/DF, Rel. Min. Moreira Alves, DJ de 21 de setembro de 1990. Available at: <http://redir.stf.jus.br/paginadorpub/paginador.jsp?docTP=AC\&docID=81908>. p. 58 .

33 See SABRA, Paula Rodrigues. Mandado de Injunção: há uma resposta do Poder Legislativo ao instituto? 2008. Accessible in: <http://www.sbdp.org.br/arquivos/monografia/127_paula.pdf>.

34 We can highlight some cases: retirement of public employees with disabilities or engaged in hazardous activities (article 40, paragraph 4); advance notice of dismissal in proportion to the length of service, of at least thirty day (article 7, XXI); right to strike of public servants (article 37, VII); guarantee of a monthly benefit of one minimum wage to the handicapped and to the elderly who prove their incapability of providing for their own support or having it provided for by their families (article 203, V) and many others.

35 The reasoning problem is also decisive for questioning the legitimacy of the court when adjudicating social and economic rights that usually refer to social and collective goods that must be enjoyed by a large part of the society. Traditional examples in the CF/88 are the right to healthcare (article 196: "health is a right of all and a duty of the State and shall be guaranteed by means of social and economic policies aimed at reducing the risk of illness and other hazards and at the universal and equal access to actions and services for its promotion, protection and recovery") and education (article 205: "education, which is the right of all and duty of the State and of the family, shall be promoted and fostered with the cooperation of society, with a view to the full development of the person, his preparation for the exercise of citizenship and his qualification for work"). In these cases, the court has to come out with a distributive and proportional reasoning that is able to mediate the simultaneous access of different individuals and groups. Since there is no clear position, it is problematic to understand the role and the common institutional goals of the STF when deciding these cases.

36 The only two issues that were regulated as a response was regarding tax law and electoral from the MI 284 and 232 cases. See Sabra supra note 24.

37 See Supremo Tribunal Federal. MI 721/DF, Rel. Min. Marco Aurélio, DJe de 30 de novembro de 2007. Available at: < http://redir.stf.jus.br/paginadorpub/paginador.jsp?docTP=AC\&docID $=497390>$.

38 See supra note 37.

39 See Supremo Tribunal Federal. MI 670/ES, Rel. Min. Gilmar Mendes, DJe de 31 de outubro de 2008. Available at: <http://redir.stf.jus.br/paginadorpub/paginador.jsp?docTP=AC\&docID=558549>.

40 See supra note 39.

41 This data must be contextualized, although ADI by omission exists since 1988, until 2008 there was no procedural distinguishing between $\mathrm{ADI}$ and $\mathrm{ADI}$ by omission, thus, some omission cases could be filed under regular ADI procedures and were not included in the STF database.

42 The ADI by omission procedure was only regulated with the Law 12.063/2009.

43 See the STF Database, available at: <http://www.stf.jus.br/portal/cms/verTexto.asp?servico=estatistica $>$.

44 See Supremo Tribunal Federal. ADC 29/DF, Rel. Luiz Fux, DJe de 29 de junho de 2012. Available at: < http:// redir.stf.jus.br/paginadorpub/paginador.jsp?docTP $=\mathrm{TP} \&$ docID $=2243342>$ and Supremo Tribunal Federal. ADC 30/DF, Rel. Luiz Fux, DJe de 29 de junho de 2012. Available at: < http://redir.stf.jus.br/paginadorpub/ paginador.jsp?docTP $=$ TP\&docID $=2243411>$

45 Another interesting case of institutional dialogue occurred in ADI 3772 that debated if the time of service outside the classroom was computed for teachers' retirement. STF recognized the constitutionality of the Law 11.301/2006 that modified the Court's interpretation (súmula 726). Before the act was approved, STF did not computed the teacher's time of service outside the classroom, however, after the act, STF admitted that the 
working time in the function of pedagogical advisory and school management should be computed as working hours for the retirement (STF - ADI 3.772/DF, Rel. Min. Ricardo Lewandowski, DJe de 26 de março de 2009).

46 Since 2004 STF has already issued 56 binding precedents (súmula vinculante).

47 The judicialization of policy culture can be briefly understood as the systematically judicial interference of the courts in areas that are historically reserved for other branches of government and legislature. For an important description of the Brazilian case see RIOS-FIGUEROA, Julio; TAYLOR, Matthew. Institutional Determinants of the Judicialisation of Policy in Brazil and Mexico. Journal of Latin American Studies, v. 38, n. 4, p.739-766, 2006.

48 This was pointed out by Julio Rios-Figueroa and Matthew Taylor about the STF case. They argued that the wider the range of judicial review channels available, the greater the likelihood that judicial review will be used as a policy action and in the long run the judicialization of policy deliberations are less likely to lead to the efficient resolution of policy debates, mainly because courts will be activated in multiple ways to decide on the same issue. See Rios-Figueroa and Taylor supra note 30.

49 The emergence of new institutions also contributed to the increase of the political intervention of the judiciary. In this respect, it stands out the new Public Prosecutor Office (Ministéro Público) in Brazil that not only was the accusatory part in criminal trials, but also in the late 1980s become an effective institution for investigation and fill actions of misconduct surveillance in the political system. The prosecutor in Brazil can easily file any actions, terms of adjustment and other procedural and non-procedural actions against governments. See generally ARANTES, Rogério. The Federal Police and the Ministério Público. In: POWER, Timothy; TAYLOR, Matthew. Corruption and Democracy in Brazil. Notre Dame: University of Notre Dame Press, 2010. p. 184-217.

50 See ARIDA, Pérsio.; BACHA, Edmar; LARA-RESENDE, André. Credit, interest and jurisdictional uncertainty: conjectures on the case of Brazil. In GIAVAZZI; GOLDFAJN; HERRE- RA (Org.). Inflation targeting, debt, and the Brazilian experience: 1999 to 2003. Cam- bridge, MA: MIT Press, 2005.

51 After the end of military dictatorship, the Brazilian political system underwent to a few specific changes like: in 1994 for presidential term of four years, in 1997 for the reelection of presidents, governors and mayors, in 1999 was approved the criminalization of buying votes and in 2010 was approved the Clean Slate Act (Lei da Ficha Limpa). All these examples are punctual transformations and within the last ten years the National Congress tried five attempts to pass a broad political reform without success.

52 Not surprisingly the "populism" was a big hit in Latin America, see the case of Lula in Brazil, Kirchner family in Argentina, Hugo Chavez in Venezuela, Evo Morales in Bolivia and Rafael Correa in Ecuador.

53 One of the problems of Brazil's political system is the difficult to operate in the presidential coalition model since the executive suffers from a continues lack of a base of congressional support that is needed to govern in the 'constitutionalized policies' scenario. Traditionally, the executive forms a majority coalition by bargaining for legislative support by favoring parliamentarians with government positions or release of funds. However, in Brazil, this situation has never resulted - in the first place - of a strongly established agreement by the parties, but rather as a result of personal interests and agendas. This practice has been severely critiqued recently by the Brazilian population after the scandals of corruption revealed by the judiciary.

54 Some key proposals are the end of reelection for executive positions, five-year terms for all positions - currently, the term of four years for all positions except the senators, whose term of office is eight years - campaign finance restrictions of certain donations, unification of the date of the elections for all positions beginning in 2022 and the reduction from 35 to 30 the minimum age for election for senator.

55 Since 2013 many protest took place on the streets of Brazil, many of them were social movements that had a common thrive: the dissatisfaction against the political system and the wave of corruption scandals with executive and legislative branches that were revealed by the judiciary in two cases (Mensalão and Lavajato).

56 See KAVANAGH, Aileen. What's So Weak About Weak-Form Review? The Case of the UK Human Rights Act 1998. Int J Const Law, v. 13, n. 4, p. 1008-1039, 2015.

57 See LOPES, José Reinaldo de Lima. Brazilian courts and social rights: a case study revisited. In: GARGARELLA, Roberto; DOMINGO, Pilar; ROUX, Theunis. Courts and social transformation in new democracies: an institutional voice for the poor? [S.1.]: [s.n.], 2006.

58 See GARDBAUM, Stephen. Are strong constitutional courts always a good thing for new democracies? Columbia Journal of Transnational Law, United States, v. 53, n. 2, p. 285-320, 2015. p. 285. 


\section{DESENHO CONSTITUCIONAL E O MODELO BRASILEIRO DE CONTROLE DE CONSTITUCIONALIDADE: REFLEXÕES SOBRE O CONTROLE JUDICIAL FORTE E FRACO PELO SUPREMO TRIBUNAL FEDERAL}

\section{RESUMO}

$\mathrm{O}$ artigo discute o tema do controle de constitucionalidade a partir da análise do desenho normativo fixado pela Constituição Federal de 1988 e por meio da classificação entre as formas de controle judicial forte e fraco, distinção tradicionalmente aplicada aos membros da Commonwealth. Desde do final da ditadura militar, na década de 1980, o Brasil aposta em um modelo que combina uma forte supremacia judicial e um controle judicial híbrido de constitucionalidade, centralizado em grande medida na atuação da suprema corte do país. Todavia, no nível normativo-estrutural, o modelo de controle de constitucionalidade brasileiro pode operar de uma maneira fraca, quando o Congresso Nacional assume um protagonismo para decidir alguns casos de constitucionalidade. Tal compreensão é alcançada após as análises de alguns julgados e provisões constitucionais. Ainda que o Congresso Nacional dificilmente anule - de maneira responsiva - as decisões de controle de constitucionalidade do Supremo Tribunal Federal, devido aos custos políticos e compromissos estratégicos, o controle judicial fraco pode ser exemplificado por dois mecanismos de controle de constitucionalidade: a forma concreta e indireta de controle pelo mandado de injunção, que protege direitos fundamentais, e a forma abstrata e direta pela ação declaratória de constitucionalidade por omissão. Ambos mecanismos transferem, em tese, a palavra final sobre o controle de constitucionalidade para o legislador, e dados da década de 1990 confirmam que, na prática, a suprema corte possuía uma posição mais restrita ao poder de revisão nos casos de omissão. Finalmente, o principal objetivo do artigo é estabelecer um diálogo com a literatura do controle fraco de constitucionalidade e permitir uma discussão ampla do modelo. Afinal de contas, em um projeto ideal de estado de direito constitucional, não apenas juízes desempenham um papel importante, mas também a participação do legislativo e do executivo são imprescindíveis.

Palavras-chave: Desenho Constitucional. Supremo Tribunal Federal. Controle Judicial Forte de Constitucionalidade. Controle Judicial Fraco de Constitucionalidade.

Submetido: 17 abr. 2017

Aprovado: 8 maio 2017 